\title{
K EXISTENCI SÝPKY NA HRADĚ VE STŘEDOVĚKU
}

\author{
JIŘÍ VARHANÍK
}

\begin{abstract}
Abstrakt: Sýpka určená k uchování osiva na přiští sezónu není pravidelnou součástí středověkého hradu $v$ českých zemích. V souvislosti s ukládáním osiva v rámci rustikálního hospodářství hrady žádnou funkci neplnily. Pokud se sýpka na hradě vyskytovala, šlo o součást vrchnostenského dvora, situovaného v některých př́padech na předhradí. Na hradech se ovšem uchovávaly nezbytné zásoby určené k přmé spotřebě. Prostory k jejich ukládání se však nevyvinuly v nějaký charakteristický stavebni typ. S tímto stavem kontrastuji rozmérné stavby z obdobi pozdni gotiky na významných šlechtických hradech Pernštejn, Švihov a Bechyně, v novějši literatuře interpretované jako sýpky, jaké se však na jiných velkých hradech té doby nevyskytují. Rovněž úroveň šlechtického podnikání v této době takovému využití neodpovídá. Vyvstává proto otázka, zda předimenzované sýpky nepředstavovaly spiše poněkud svérázný projev šlechtické reprezentace než součást plně funkčního hospodářského zázemí uvedených hradi̊.
\end{abstract}

Klíčová slova: hrad-sýpka-obili-osivo-rustikál-dominikál.

\section{Silos in medieval castles}

Abstract: Silos for storing grain for the next season were not regular features in medieval castles in the Czech lands. Castles did not perform any function in the storage of grain within rural economy; if there was a silo, it was part of an aristocratic homestead situated, in some cases, in the bailey. Although castles had necessary supplies for direct consumption, the spaces for their storage did not develop into any characteristic building type. This situation is contradicted by the existence of large structures from the late Gothic in several major castles held by the nobility such as Pernštejn, Švihov and Bechyné, interpreted in recent literature as silos which, however, did not feature in any other large castles of the period. The level of economy of the aristocracy in this period does not suggest this use, either. The question remains as to whether the huge silos presented a somewhat peculiar kind of aristocratic representation, rather than genuine parts of the economic hinterland of the mentioned castles.

Key words: castle - silo-corn - grain - rural-dominical.

Jedním z důsledků převratných změn, které v českých zemích proběhly ve 13. století, byl též počátek masové výstavby kamenných hradů, které se staly, byt' ve většinou pozměněné podobě následkem pozdějších přestaveb a často po svém opuštění ve stadiu zrrícenin, jedním z neodmyslitelných atributů zdejší krajiny. Ještě dalekosáhlejší proměnu však představoval přechod z naturálního na peněžní hospodářství (Klápště 2012). Přeměnu poddanských dávek v převažující platy provázela od konce 13. století tendence $\mathrm{k}$ transformaci dosavadního dominikálu v rustikál, který mohl přinášet vrchnosti výnos v hotových penězích, aniž bylo nutné věnovat správě tohoto majetku nějakou zvláštní péči a vynakládat na ni další prostředky (Graus 1957, 73). Peněžní forma renty převažovala a naturální dávky v podobě obilí a některých dalších potravin měly pouze doplňkový charakter (Macek 1999, 100). Rozsah těchto dávek, jakož i robotních povinností na konci 14. století je dobře doložen, např́iklad urbáři na panství arcibiskupského hradu Hefenburka u Úštěku (Gabriel-Panáček-Podroužek 2011, 80-111). Z deseti vsí a jednoho malého města činila naturální renta mimo jiné 118 korců pšenice a stejné množství žita. Většina hradů však měla zázemí podstatně menší (Vohryzek-Kovář-Hlavica 2015). Další obilí, které nebylo určeno ke spotřebě a k uchování jako osivo, mohli rolníci prodat na trhu. Zatímco pro vrcholný středověk je předpokládán obchod s obilím včetně frekventovaného vývozu (Graus 1957, 51-56), pro jagellonské období se uvádí tržní produkce obilí poměrně nízká s tím, že ani růst poddanského obilnářství od konce 15 . století nepostačoval k soustavnému vývozu ve větším množství (Macek 1992, 68). Zemský sněm v roce 1479 však s jeho vývozem počítal, nebot' jej povolil všem, kdo na české trhy přiváželi zboží (Macek 1992, 115).

Vedle celé řady funkcí hradů v životě stř̌edověké společnosti bývá zmiňována také jejich role hospodářská (Durdík 1983). Na úlohu hradů v oblasti zemědělské výroby, konkrétně na prŕípadné ukládání osiva na př́íší rok, je pohled dosavadní literatury značně rozporuplný. 
Uchovávání zemědělských zásob se předpokládá v sýpkách, situovaných většinou na předhradí (Musil 2006, 261). Podle T. Durdíka (1999a, 36-37) byla sýpka většinou součástí prvních nádvoří hradu s tím, že s rozvojem šlechtického podnikání se vyskytovaly výstavné zděné sýpky (např. Švihov, Bechyně), jinde se uvádí, že jejich výskyt v této souvislosti až koncem 15. století byl spíše výjimečný (Durdík-Bolina 2001, 67). Dále bývá zdůrazňován rozdíl mezi královskými a šlechtickými hrady, přičemž se předpokládá, že královské hrady představovaly výhradně spotřebitelské prostředí, nicméně se připouští, že u královských hradů byly samostatné objekty sloužící ke skladování hospodářských produktů v jejich předních částech (Durdík 1999a, 37).

Poměrně hustá sít' kamenných hradů by tak mohla svádět k představě, že sýpky situované za jejich pevnými hradbami byly $\mathrm{v}$ nejistých dobách nejvhodnějším místem $\mathrm{k}$ bezpečnému uchovávání osiva na příští sezónu, které mělo jako záruka budoucí úrody pro celou středověkou společnost životně důležitý význam. Takováto hypotéza byla zcela nedávno formulována v souvislosti s úvahou o využití prostor v přizemí královského paláce na Bezdězu. Její autoři usuzují, že zde mohlo být skladováno obilí určené pro setbu po válečných událostech, při nichž byly ztraceny zásoby obilí v okolních sídlech (Gabriel-Kracíková 2016, 28-29). Využívání přízemních prostor hradních budov k ukládání zásob všeho druhu bylo předpokládáno již dříve (Durdík-Bolina 2001, 67). Otázkou ovšem zůstává, zda zde mohlo být ukládáno osivo pro rustikální hospodářství, nebot' není zřejmé, odkud by taková další rezerva osiva měla pocházet. Znamenalo by to totiž, že by se obilí ukládalo na hradě vlastně duplicitně, tedy vedle obvyklých vesnických sýpek, k čemuž by však produkce středověkého zemědělství sotva mohla postačovat. $\mathrm{V}$ takovém případě by rolníci museli vzhledem k nízkým výnosům deponovat na hradě poměrně velkou část přebytku ze své sklizně, který ovšem potřebovali prodat na trhu, aby získali hotové peníze, nezbytné jak na placení poddanského úroku, tak na pořizování dalších životních potřeb, které si nedokázali opatřit svépomocí. Kromě toho zprávy písemných pramenů nic nevypovídají o nezbytné redistribuci uloženého osiva zpět mezi rolníky, která by vyžadovala nemalé organizační nároky a vzhledem ke své povaze by zajisté byla předmětem sporů, o nichž by - alespoň z pozdního středověku - sotva mohly být veškeré písemnosti ztraceny.

Menšinové dominikální hospodářství bylo soustředěno zejména ve vrchnostenských dvorech, jejichž součástí byly také sýpky (Graus 1957, 67). Přetrvávající dominikální trh nebyl rovnocenný svobodnému trhu (Petráňovi 2000, 125). Ani v době jagellonské ještě nešlo o střediska specializované výroby, jako tomu bylo v pokročilém 16. století, naopak ještě v této době, často spojované se snahami o šlechtické podnikání, docházelo k jejich rozprodeji měštanům a poddaným (Macek 1994, 155). V literatuře byla věnována pozornost zejména vztahu vrchnostenského dvora a tvrze (Chotěbor-Smetánka 1985; Kašička 1985). V důsledku obdobných vztahů mezi dvorem a hradem se sýpka mohla vyskytovat na hradě, byl-li poplužní dvůr součástí předhradí (Novák 2016, 136). Takové př́ípady jsou velmi obtížně prokazatelné, ze zkoumaného vzorku 29 předhradí je dvůr jako jeho součást předpokládán v pouhých čtyřech př́ípadech (Hložek 2006, 33). A. Sedláček $(1934,182)$ zmiňuje existenci dvora na předhradí hradu v Hořovicích, avšak neuvádí, zda zde existoval již ve středověku. O ukládání obilí na hradech ve středověku poskytují historické prameny jen dílčí informace. Písemné prameny nepostihují stavební podobu sýpek, a pokud se zmiňují o obilí, šlo nejspíše o zásobu určenou k prrímé spotřebě, jako v roce 1461 na Maidštejně, kde se mj. uvádí vedle sladu též vymlácené a nevymlácené obilí (Rynešová-Pelikán 1954, 444). Sotva uvěřitelný je údaj uváděný A. Sedláčkem (1932, 113), že při požáru - dne 9. dubna 1522 - Horního hradu na Rožmberku, jehož součástí byl poplužní dvůr, shořelo 12000 čebrů žita. Podle G. Hofmanna $(1984,54)$ představuje objemová míra čebr čtvrt sudu a obnáší 1,12-1,24hl. Početné pozdější zprávy o sýpkách na hradech samozřejmě nelze mechanicky přenášet do odlišných stř̌edověkých poměrů.

Jednoznačné poznatky v tomto směru nepřinášejí ani výsledky stavebněhistorických průzkumů a archeologických výzkumů, nebot' ani ty vždy nevedou bez problémů ke spolehlivé identifikaci objektu sloužícího k uchovávání osiva. V prrípadě stavebněhistorického průzkumu, je-li jeho předmětem jen torzálně dochovaná architektura, sice lze zevrubně analyzovat veškeré její detaily, avšak jednoznačně stanovit účel stavby, resp. jejího konkrétního interiéru, může být 
obtížné a je zpravidla závislé na analogiích s obdobnými, lépe zachovanými budovami z jiných lokalit. Podobně je tomu u archeologického výzkumu, jehož velkou předností oproti obvyklému povrchovému stavebněhistorickému průzkumu je možnost zachytit stopy někdejšího užívání stavby pod úrovní terénu. Ukládání obilí ve větším množství je však bezpečně prokazatelné pouze ve vzácných př́ípadech, pokud došlo k destrukci objektu právě v době, kdy v něm bylo uchováváno. $\mathrm{V}$ dolním paláci hradu Rokštejna u Brtnice, zaniklém požárem v době husitské, byly zjištěny mj. zuhelnatělé obilky (Měřínský 2007, 81), ovšem není jisté, zda budova obsahovala prostor určený od počátku, resp. od rozdělení hradu mezi dva majitele, k uchovávání obilí, či zda šlo jen o přechodné využití v době domácí války. Na hradě v Lelekovicích je na základě archeologického výzkumu předpokládáno ukládání obilí v části jedné z přízemních místností hospodářského objektu, opatřeného stoupou (Unger 1991, 233).

Situaci zásadně komplikuje skutečnost, že ze zástavby předhradí, kde by se sýpka jako součást poplužního dvora mohla případně vyskytovat, se většinou dochovalo jen minimum zděných konstrukcí, a archeologické výzkumy byly v těchto místech realizovány jen v nevelkém rozsahu (Hložek 2006, 32). Výjimku představuje rozsáhlý archeologický výzkum velké části předhradí ve Veselí nad Moravou, avšak žádný z celkem osmnácti zjištěných stavebních objektů nebyl interpretován jako sýpka (Plaček-Dejmal a kol. 2015, 326-327).

V této souvislosti je třeba zdůraznit, že pokud se vůbec ukládání obilí na hradě prokáže, je velmi obtížné důsledně odlišit stopy uchovávání osiva, určeného k výsevu na dominikální půdě, tedy jako předpokladu provozu vrchnostenského dvora, od nezbytného ukládání zásob, jimiž musel být hrad vybaven pro př́ípad nepředvídaných událostí, z nichž dlouhodobé obležení $\mathrm{s}$ hrozícím vyhladověním patřilo až ke krajním z nich. Běžné kořistnické vedení války ve středověku se soustř̌ed’ovalo právě na likvidaci ekonomického zázemí protivníka a postihovalo tak zejména venkovské obyvatelstvo (srov. např. Vorel 1999, 64). Odhánění dobytka představovalo podstatně efektivnější způsob takovéhoto postupu než loupení obilí, k němuž však patrně také docházelo. Za takových okolností mohlo být zásobování hradu značně ztíženo, aniž by muselo dojít k úplnému znemožnění kontaktu s jeho zázemím. I když tedy měly skladovací prostory pro uchovávání potravin pro život na hradě zásadní význam, nevyvinulo se žádné jejich typické stavební řešení, cíleně zaměřené k tomuto účelu. U prostor, jimž je přičítán skladovací účel, je dále vhodné přihlížet k jejich kvalitativnímu rozlišování na „vlhké“ a „suché“ (Ryk1 2011); na vzlínající vodu v přízemí královského paláce na Bezdězu upozorňují F. Gabriel a L. Kracíková $(2016,28)$. Tento jev ostatně musel zákonitě ovlivňovat klima ve všech nevytápěných přízemních prostorách kamenných budov na hradech, zvláště pokud nebyly podsklepeny.

Pražský hrad rozhodně nebyl charakteristickým vrcholně středověkým hradem a jeho utváření bylo determinováno předchozí tradicí. Jak uvádí tzv. pokračovatel Kosmův, v červnu roku 1253 nechal král Václav I. v obavách ze vpádu Kumánů a dalších nepřátel shromáždit obilí a zásoby dalších potravin, které byly uloženy v kostele sv. Jiř́i na Hradě, přičemž jeptišky se musely ubytovat ve městě (FRB II, 291). Jak vyplývá z této zprávy písemných pramenů, ani Pražský hrad nebyl vybaven specializovanou stavbou určenou k uchování obilí. V uvedeném případě nejspíše šlo o obilí k př́ímé spotřebě, nebot' v uvedené roční době bylo osivo již zaseto, ale období sklizně ještě nenastalo. Toto mimořádné opatření tedy nelze spojovat se zabezpečením zásoby osiva na př́ští rok.

Poněkud neobvyklým příspěvkem ke zde sledované problematice byl návrh nově interpretovat džbánovité objekty, situované převážně na hradech a vyhloubené v pískovcovém podloží, které byly v literatuře doposud považovány za vězení či cisterny, jako zásobnice potravin, především asi obilí (Gabriel-Knop 1990). Autoři považovali za výhody takového ukládání dobrou konzervaci obilek, zaručenou jak stálostí teploty, tak samokonzervací a vyloučením působnosti hmyzu. Pro středověké poměry se jim dále jevilo jako významné, že takto uložené potraviny byly chráněny před požárem a při dobrém zamaskování před zcizením. Připouštějí, že ukládání obilí v jamách mohlo přežívat i v dobách, kdy se již vžil pokročilejší způsob jeho ukládání v nadzemních objektech, s tím, že zatímco obilí v nich uložené mohlo sloužit přímé spotřebě, obilí v jámě představovalo rezervu pro nejhorší případ, sloužící prrípadně i jako zdroj osiva pro 


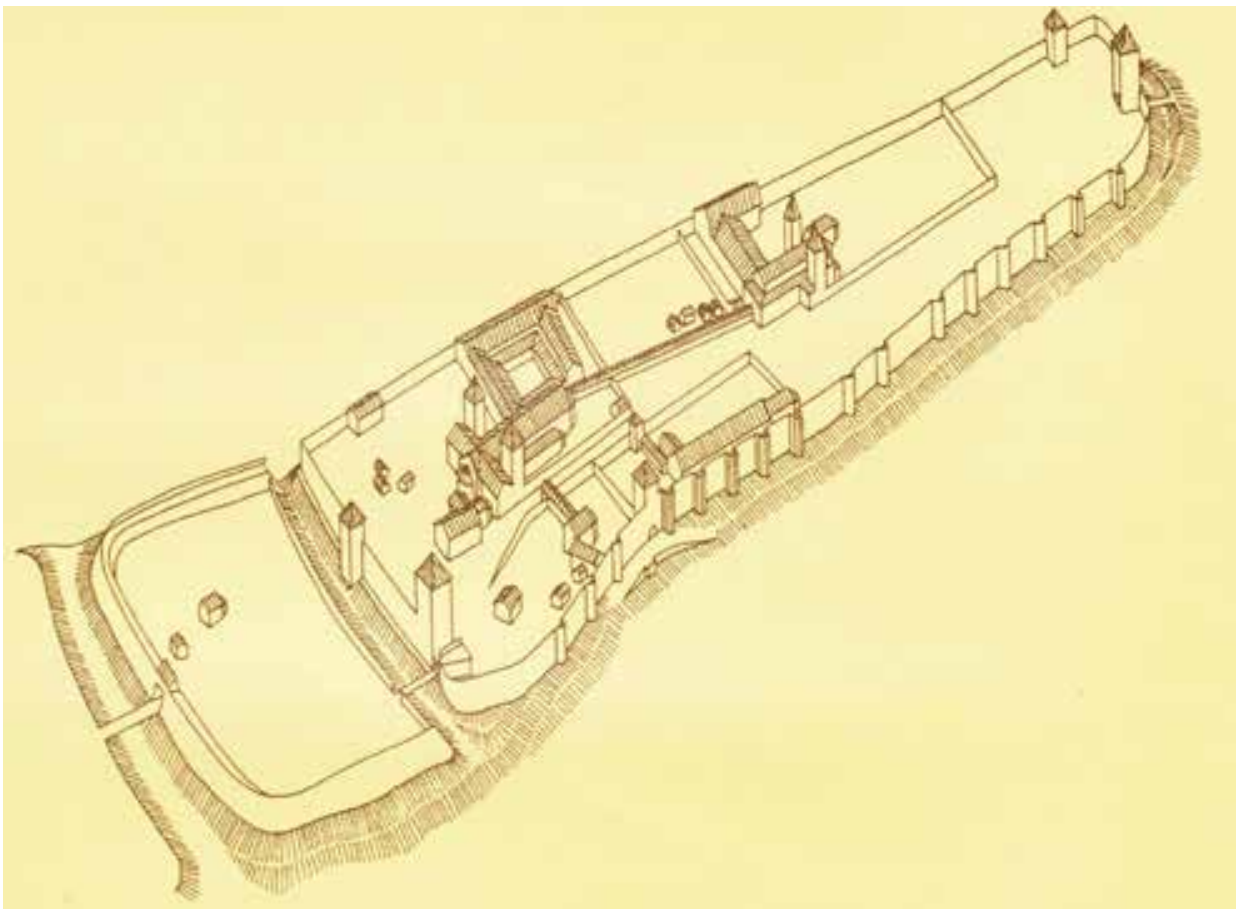

Obr. 1. Pražský hrad na konci 12. století. Kresba P. Chotěbor.

Abb. 1. Prager Burg am Ende des 12. Jahrhunderts. Zeichnung P. Chotěbor.

zemědělce př́íslušející pod správu hradu. Tento názor byl poněkud nekriticky převzat do syntetické literatury (Durdík 1999, 535).

Pozoruhodné byly v této souvislosti výsledky pokusu provedeného na hradě Frýdštejně v létě roku 1987: Do zahloubeného džbánovitého objektu cisterny bylo napuštěno $6 \mathrm{~m}^{3}$ vody, jejíž hladina dosáhla úrovně $3,3 \mathrm{~m}$ nade dnem. Voda však během šesti dnů vytekla, což bylo považováno za hlavní argument proti využití objektu jako cisterny. Autoři sice připouštějí, že zajištění vodotěsnosti bylo ve středověkých podmínkách proveditelné, avšak na Frýdštejně se po něm nezachovaly žádné stopy (Gabriel-Knop 1990, 269-270). K tomuto zajímavému experimentu je ovšem třeba dodat, že podobně jako prosákla pískovcem voda, „vytekl“ by z takovéto obrovské zásobnice také oxid uhličitý, čímž by byl samokonzervační efekt v ní uloženého obilí přirozeně vyloučen. ${ }^{1} \mathrm{~V}$ opačném prŕípadě, pokud by šlo o zahloubený objekt s neprodyšnými stěnami a dnem, by při uskladnění většího množství obilí bylo nejspíše životu nebezpečné do takovéto zásobnice sestupovat.

K případnému ukrývání zásoby obilí uložené na hradě je třeba připomenout, že zatímco u vesnického obyvatelstva mělo eventuální tradiční uložení osiva v zamaskované jámě za nejistých stř̌edověkých poměrů zásadní význam, na hradě tomu bylo jinak, nebot' odcizení obilí přicházelo v úvahu prakticky pouze $\mathrm{v}$ prrípadě jeho dobytí nepřítelem. Po dobytí a na něj zpravidla navazujícím obsazení hradu posádkou útočníka měl jeho původní držitel jen malou naději, že by se obilí, i kdyby bylo sebelépe zamaskované, v dohledné době domohl, nebylo-li sjednáno zpětné vydání hradu jeho uchvatitelem.

Za doklad sýpky jako součásti hradu byla považována nálezová situace na Kozím hrádku u Tábora. Jádro dvojdílného hradu, které obíhal vodní příkop s vnějším valem a parkán

1 Za konzultaci děkuji RNDr. J. Zavřelovi. 


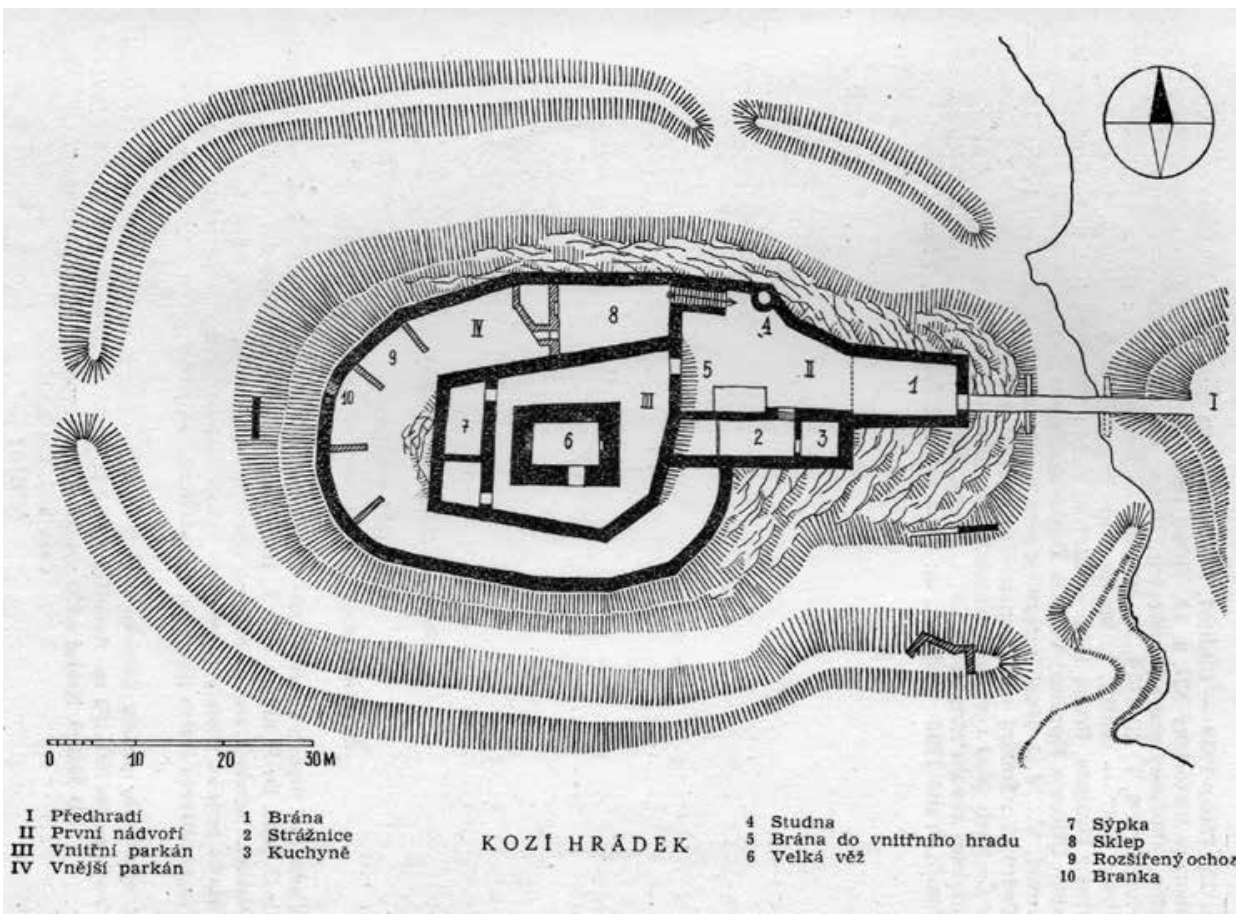

Obr. 2. Kozí hrádek. Plán podle Menclová 1956.

Abb. 2. Ziegenburg. Planskizze nach Menclová 1956.

s hospodářskými objekty, sestávalo z hranolové obytné věže stojící volně uprostřed vnitřního hradebního okruhu, k němuž na západní straně přiléhala podélná dvouprostorová budova. V její menší, jižní místnosti bylo při výkopu J. Švehly $(1920,28)$ nalezeno „,několik měr" spáleného žita a v koutech nespálené plevy. Jakkoli provádění výkopů nebylo podrobně dokumentováno, není důvod nález zpochybňovat. Autor uvedený prostor interpretoval jako sýpku. D. Menclová $(1956,3)$ naproti tomu označila za sýpku celou budovu a uvedla odůvodnění, že chránila základní obživu hradních obyvatel. $Z$ toho odvozovala její zděnou podobu a prejzovou krytinu chránící proti ohni. Hrad byl ovšem zděný víceméně celý a stejná krytina se uplatňovala také na obytné věži, jak bylo zjištěno výkopem. Později ve své syntetické práci autorka zdůraznila, že sýpka obsahovala to nejcennější, co malý venkovský šlechtic, v té době napůl sedlák, měl - osivo, které bylo zárukou budoucí úrody (Menclová 1972, 1, 429-430). Vzápětí však uvedla, že hrádky se lišily od tvrzí tím, že již nestály ve vesnici, odtrhly se od zemědělské výroby ve vlastní režii a žily více nebo méně jen z naturální a peněžní renty, čímž vlastně popřela své předchozí tvrzení o významu hospodaření majitele hradu na dominikální půdě. Objevil se také názor, že Kozí hrádek byl skromnou tvrzí (Vondra 1958, 149); jeho charakteristika jako tvrze ovšem není vhodná vzhledem k poloze mimo vesnici, nehledě na to, že dvoudílná dispozice a celkové uspořádání jej řadí jednoznačně mezi hrady, jakkoli náležel k menším (nikoli však k nejmenším) z nich. V další práci týkající se hradu je předmětný objekt $\mathrm{v}$ jádře hradu charakterizován rezervovaněji jako hospodářská budova, v popisce k půdorysu pak jako „zděná budova (sýpka?)“ (KrajícŠmahel 1988, 120). Zánik Kozího hrádku je kladen do souvislosti s obléháním Tábora králem Albrechtem v pozdním létě roku 1438 (Švehla 1920, 44; Menclová 1956, 15), s nezbytnou dávkou opatrnosti tedy lze formulovat předpoklad, že šlo nejspíše o obilí opatřené k př́mé spotřebě a pocházející ze sklizně tohoto roku. Př́ípadnou sýpku pro ukládání dominikálního osiva lze 


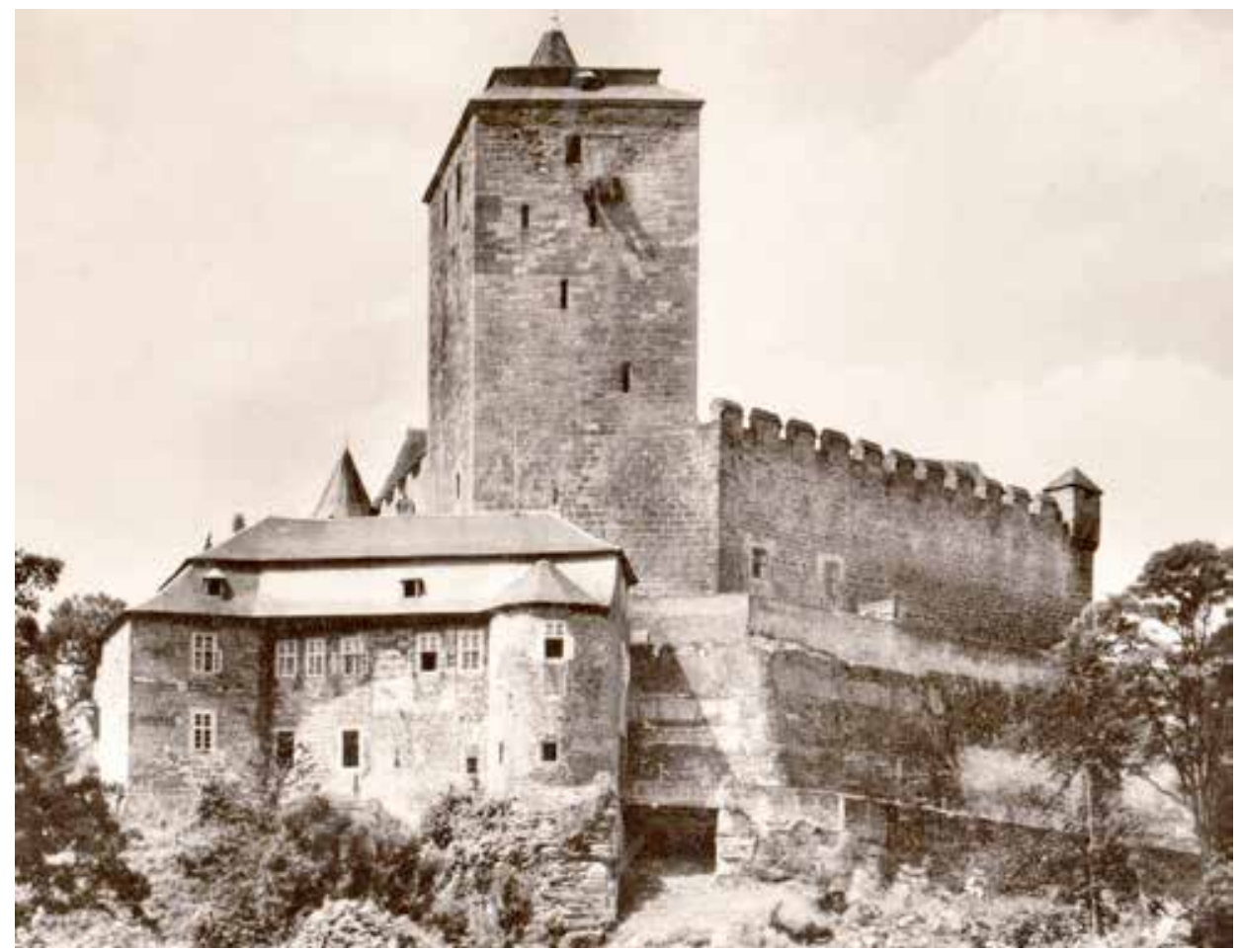

Obr. 3. Hrad Kost. Pohled od východu. Foto z archivu J. Varhaníka. Abb. 3. Burg Kost. Blick von Osten. Foto Archiv J. Varhaník.

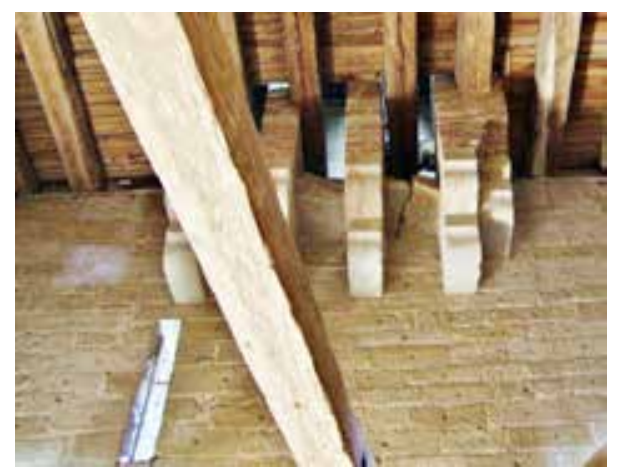

Obr. 4. Hrad Kost, interiér velké věže. Foto J. Varhaník, 2006.

Abb. 4. Burg Kost, Interieur des großen Turms. Foto J. Varhaník, 2006. je vyhrazeno její poslední patro s velkými okny, otopným zařízením a trezorem (Panáček 2003). Podle starší literatury byla nižší podlaží, spoře osvětlovaná jen poměrně vysokými, ale úzkými průduchy procházejícími tloušt'kou zdiva, které nebyly obvyklým způsobem špaletovány dovnitř, ale ponechávaly si konstantní šířku v celé své délce, vyhrazena obraně (Menclová-Wagner 1965, 4). Jako „střílnovitá“ hodnotil okénka věže ještě D. Líbal (2001, 193). Uvedené otvory však nebylo možné k obraně (Gabriel-Panáček-Podroužek 2011, 363), ba dokonce ani k účelnému 
pozorování okolí hradu použít, nehledě na to, že v době vzniku věže se ještě aktivní obrana hradů v českých zemích obecně omezovala na úroveň ochozů. Pravděpodobně právě neobvyklé utváření průduchů ve zdivu velké věže s prostornými interiéry vedlo T. Durdíka $(1995,142)$ k poněkud suverénně formulovanému, avšak ničím nedoloženému závěru, že nižší úrovně byly od počátku provedeny jako sýpka. Tento názor byl převzat $\mathrm{v}$ dalších pracích, které se hradem zabývaly (Durdík 1999, 274, 535; Panáček 2003, 130; Gabriel-Panáček-Podroužek 2011, 363). Nedávno byl dokonce propočítán odhad, že do všech pater věže by se vešlo zhruba 80 tun obilí (Knop 2015, 332). Shromáždění takového množství obilí na hradě je sotva reálné i za okolnosti, že by určitý, byt' nevelký podíl z tohoto objemu pocházel z doplňkové naturální části poddanských dávek. V této souvislosti je třeba zdůraznit, že výnos středověkého obilnářství je obvykle odhadován v průměru na čtyřnásobek výsevu (Graus 1957, 45; Macek 1992, 68; Petráňovi 2000, 94), tudíž za předpokladu, že by byly prostory ve věži za tímto účelem skutečně takto využity, docházíme k sotva pravděpodobnému číslu kolem 300 tun výnosu dominikálního hospodářství.

Po stránce stavebněhistorické není důvod přičítat neobvykle tvarovaná větrací okénka věže řešení užívanému u sýpek. Zatím jediný objekt, jemuž byla připisována takováto funkce, hospodářská budova kláštera v Plasích, je opatřen běžnými hrotitými okénky (Pavlík-Líbal 1980), přičemž jeho poslání je předmětem diskuse (Čechura-Kuthan 1982). ${ }^{2}$

Existenci sýpky na významném královském hradě Křivoklátě předpokládal T. Durdík v někdejším purkrabském paláci, který měl být k tomuto účelu upraven po vážném poškození požárem roku 1422 (Durdík 1983, 475; 1999a, 301). Autor však zároveň paradoxně zdůraznil, že královské hrady představovaly čistě spotřebitelské prostředí a nesloužily jako hospodářská centra (Durdík 1983, 471; 1999a, 37). Pokus o zmapování nejbližšího zázemí Křivoklátu žádným větším dominikálním aktivitám ve středověku nenasvědčuje (Durdík 1999b, 263-272), právě tak jako o něco pozdější hospodářská instrukce pro křivoklátského hejtmana z roku 1528 (Boukal 2017). Podle A. Sedláčka $(1935,6)$ se zde sýpka uvádí v roce 1658 , kdy se ovšem využití hradu podstatně lišilo od podmínek 15 . století.

$\mathrm{Z}$ tohoto stručného shrnutí dosavadních názorů na existenci sýpek na kamenných hradech $\mathrm{v}$ českých zemích lze tedy dojít $\mathrm{k}$ jednoznačnému závěru. Sýpka, sloužící v rámci rustikálního hospodářství k uchování osiva pro zabezpečení úrody na prŕíší rok, není charakteristickou součástí vrcholně středověkého hradu a způsob organizace ekonomického života tehdejší společnosti s hradem v tomto smyslu nepočítá. Skutečnost, že ani v souvislosti s válečnými přípravami nehrály při opatřování a ukládání zásob potravin rozhodující roli královské hrady, ale královská města, přesvědčivě dokládá situace v září roku 1362, kdy na př́ikaz Karla IV. shromáždila velké množství obilí (CIM II, 575-577 č. 398).

Sýpka se tedy mohla na hradě vyskytovat jako součást poplužního dvora na předhradí šlechtického hradu, který sloužil pouze dominikálnímu hospodářství, jehož podíl na celkové obilnářské produkci byl minoritní. Pro vrchnost bylo výhodnější zbývající dominikální půdu převést na rustikální $\mathrm{s}$ vyhlídkou na pevný plat $\mathrm{v}$ rámci emfyteutického vztahu, než pracně zajištovat námezdní síly na její obdělávání, mimo jiné také proto, že rozsah robot byl poměrně malý (k rentě obecně srov. Graus 1957, 159-193). Prostorám na hradech považovaným z různých důvodů za sýpky je tedy třeba přičítat odlišné poslání, pokud nešlo o místa, kde bylo ukládáno obilí určené k přímé spotřebě.

Naproti tomu v rolnické usedlosti bylo uchovávání osiva samozřejmostí, at' již v tradičních zahloubených jamách, nebo ve špýcharech (Petráňovi 2000, 105-106; Škabrada 1979). V souvislosti s rozšířením trojdílného komorového domu byly patrové komory spojovány s rozvojem zemědělské výroby (Frolec 1982, 69), přestože komoru nelze vždy ztotožňovat se sýpkou (Smetánka 1989, 322).

S těmito závěry však nápadně kontrastují př́iklady tř́i velkých pozdně gotických staveb interpretovaných jako sýpky - na významných šlechtických hradech.

2 Kromě toho jsou na stavbě budovy osazena ostění rozměrných románských oken, bud’ druhotně použitých, nebo původně určených jinam. 


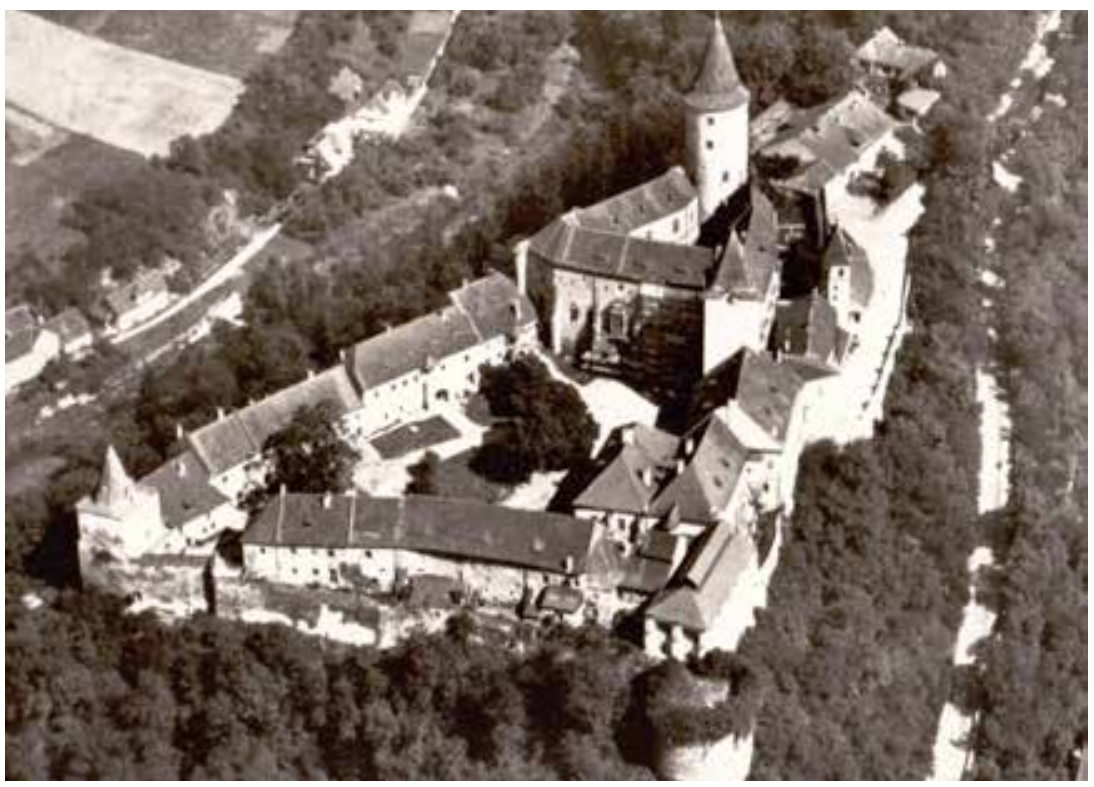

Obr. 5. Hrad Křivoklát. Letecký snímek od západu. Zdroj archiv J. Varhaníka.

Abb. 5. Burg Pürglitz. Luftaufnahme von Westen. Quelle Archiv J. Varhaník.

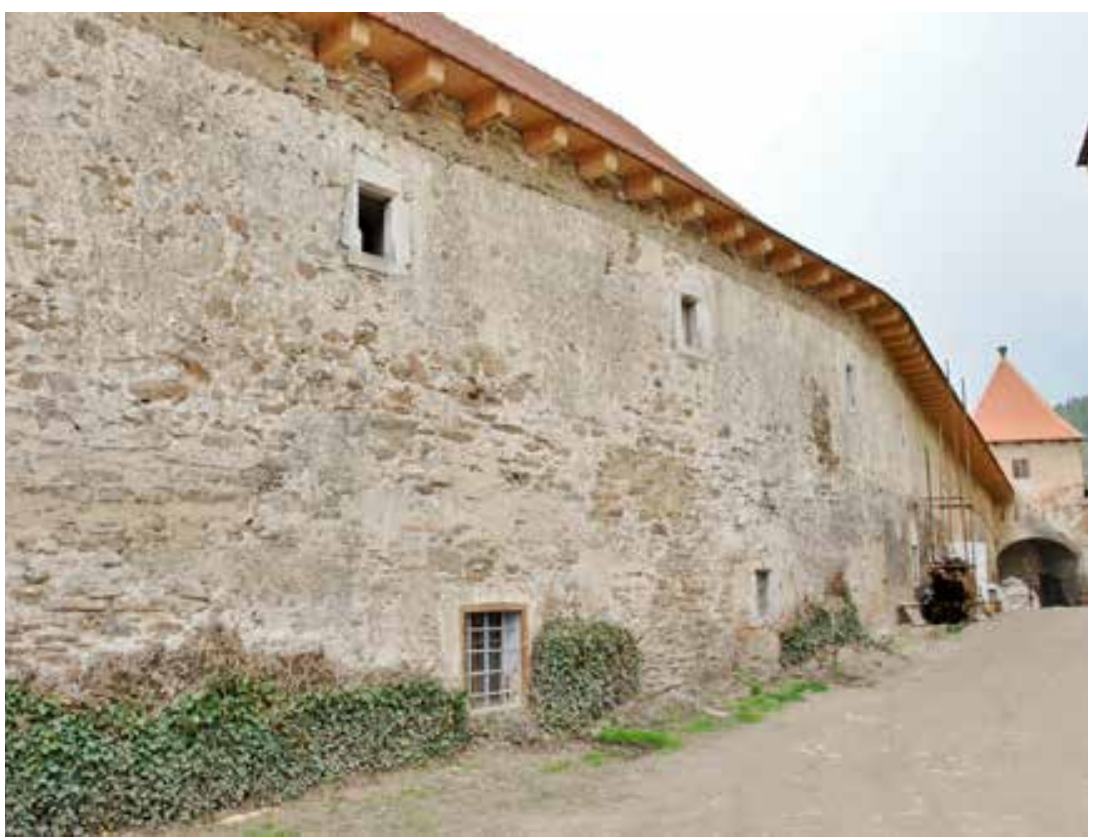

Obr. 6. Hrad Pernštejn. Nádvorní průčelí budovy na západní straně parkánu. Foto J. Varhaník, 2008. Abb. 6. Burg Pernstein. Hoffassade des Gebäudes auf der Westseite des Zwingers. Foto J. Varhaník, 2008. 
Ve starší literatuře nebyla věnována bližší pozornost objektu na moravském hradě Pernštejně, označovanému jako sýpka, který je z uvedené trojice nejstarší. Po požáru, který postihl budovy na západní straně vnitřního předhradí v roce 2005, byl proveden jejich zevrubný průzkum, který dospěl k závěru, že sýpka zde byla budována s částečným využitím starších konstrukcí ve dvou brzy po sobě následujících etapách v 60. letech 15. století, což je doloženo dendrodaty (Šabatová 2016). Otázkou zůstává, zda interiér prvního patra této budovy, tvořený jediným prostorem o délce přesahující $80 \mathrm{~m}$, skutečně sloužil k uchovávání osiva. Hrad leží v členité, nepř́iliš úrodné krajině a lze si jen těžko přestavit, že by výnos dominikálního obilnářství vyžadoval sýpku takovýchto impozantních rozměrů. K přestavbě budovy došlo za Jana I. z Pernštejna († 1475), který žil na hradě se svými třemi nezletilými syny, zatímco jejich starší bratr Vilém († 1521), známý v pozdější době svým intenzivním podnikáním, se tehdy angažoval v drobné válce s odpůrci krále Jiř́iho z Poděbrad, spočívající hlavně v plenění lichtenštejnských vsí (Vorel 1999, 6469). Za Jana I. se šlechtické podnikání na pernštejnském panství soustřed’ovalo na pokračující těžbu drahých kovů, zakládání rybníků a rozvoj rybnikářství (Samek-Plaček-Stehlík-Holíková 1997, 10). Není třeba pochybovat o tom, že na Pernštejně, stejně jako na jiných hradech, se zajisté již v 15. století vařilo pivo, ovšem v rozsahu, jaký sotva mohl vyžadovat extrémně velkých prostor pro skladování obilí. Jeho produkce $\mathrm{v}$ této době nemohla být srovnatelná $\mathrm{s}$ pozdějším rozvinutým vrchnostenským pivovarnictvím, souvisejícím se vznikem velkých panských dvorů. $\mathrm{K}$ tomu hospodářský vývoj v Čechách a na Moravě nedospěl ani později za pokročilého věku Viléma z Pernštejna (Vorel 1999, 107-108).

Rozměrná, původně dvoupatrová budova s přiléhající válcovou věží Kašperkou na jihozápadním nároží předhradí hradu Švihova byla nejprve považována za purkrabství, případně

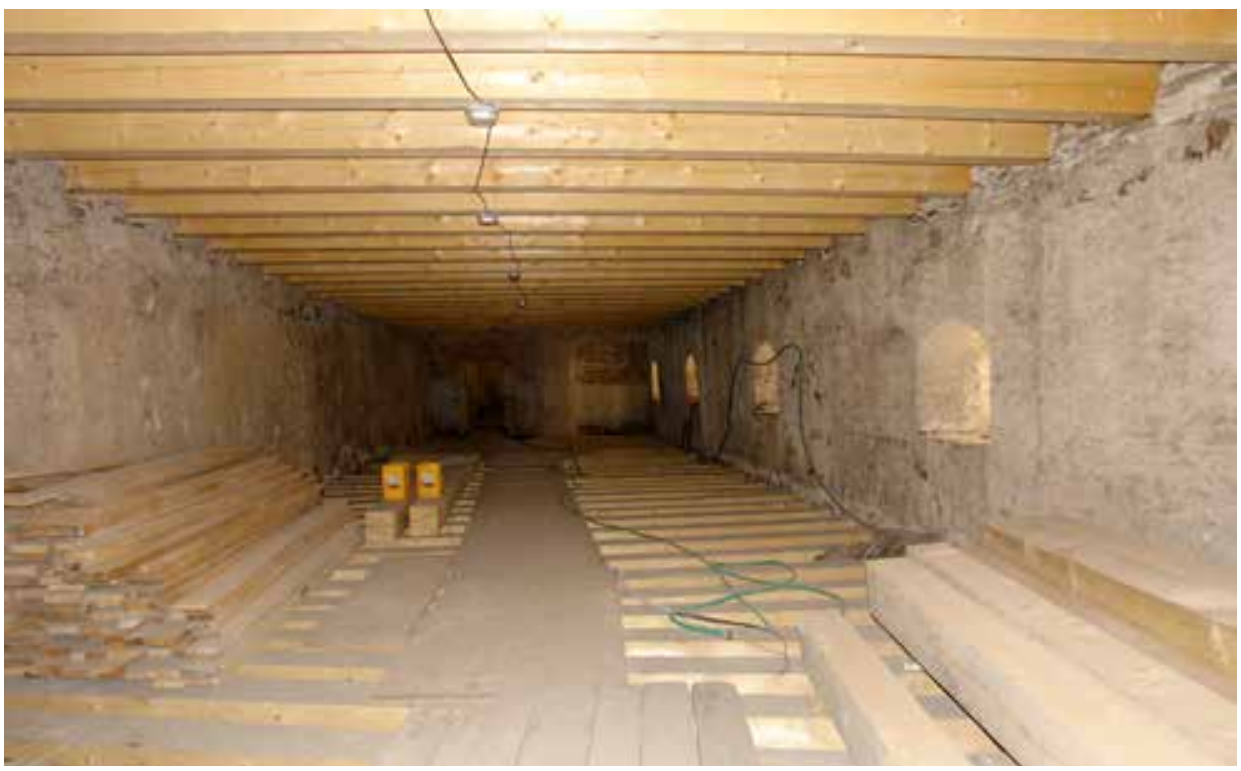

Obr. 7. Hrad Pernštejn, interiér předpokládané sýpky. Foto J. Varhaník, 2008.

Abb. 7. Burg Pernstein, Interieur des angenommenen Speichers. Foto J. Varhaník, 2008.

pivovar (Menclová 1953, 10; Štorm 1954, 180). Ve své pozdější syntetické práci se D. Menclová $(1972,2,402)$ k původnímu poslání stavby nevyjádřila a označila ji neurčitým způsobem jako „,větši patrovou budovu se stř́lnami“. Jako špýchar ji interpretoval až J. Muk v elaborátu stavebněhistorického průzkumu hradu (Lancinger-Muk 1975, 123). Autor k této etapě výstavby hradu 


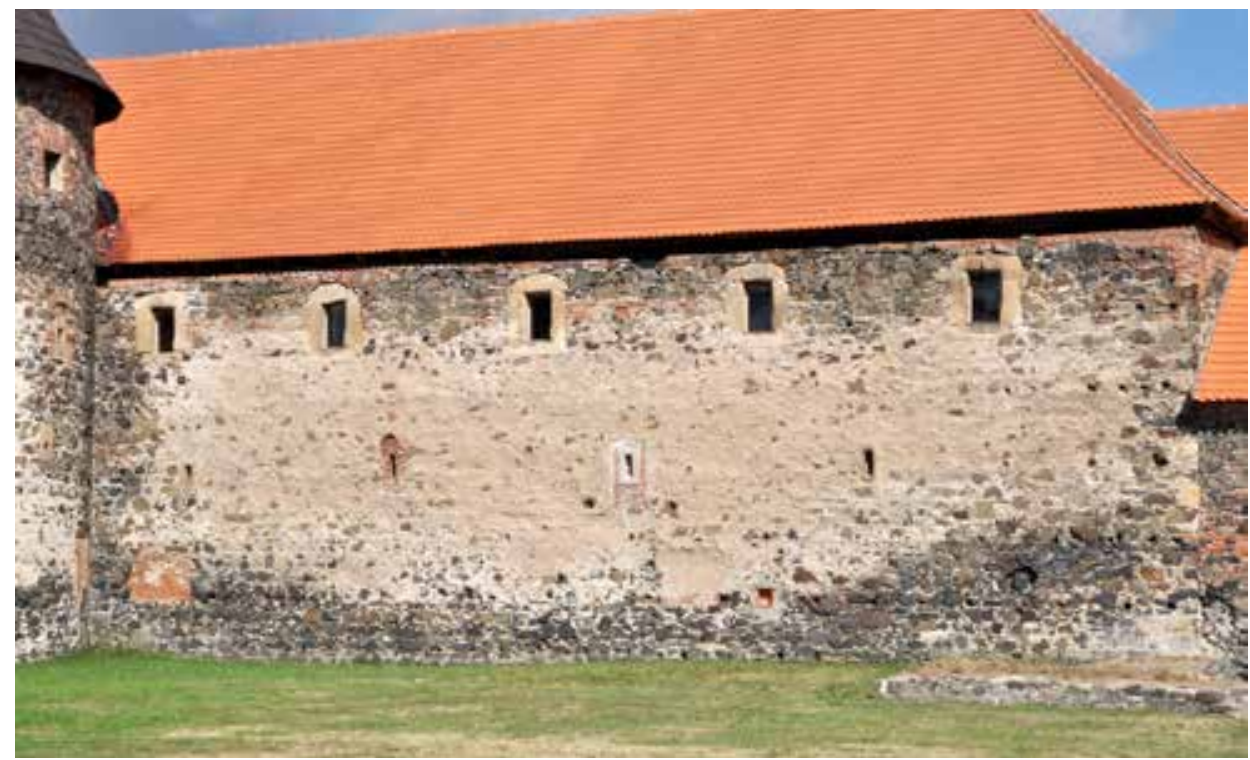

Obr. 8. Hrad Švihov, jižní průčelí sýpky. Foto J. Varhaník, 2015.

Abb. 8. Burg Schwihau, Südfassade des Speichers. Foto J. Varhaník, 2015.

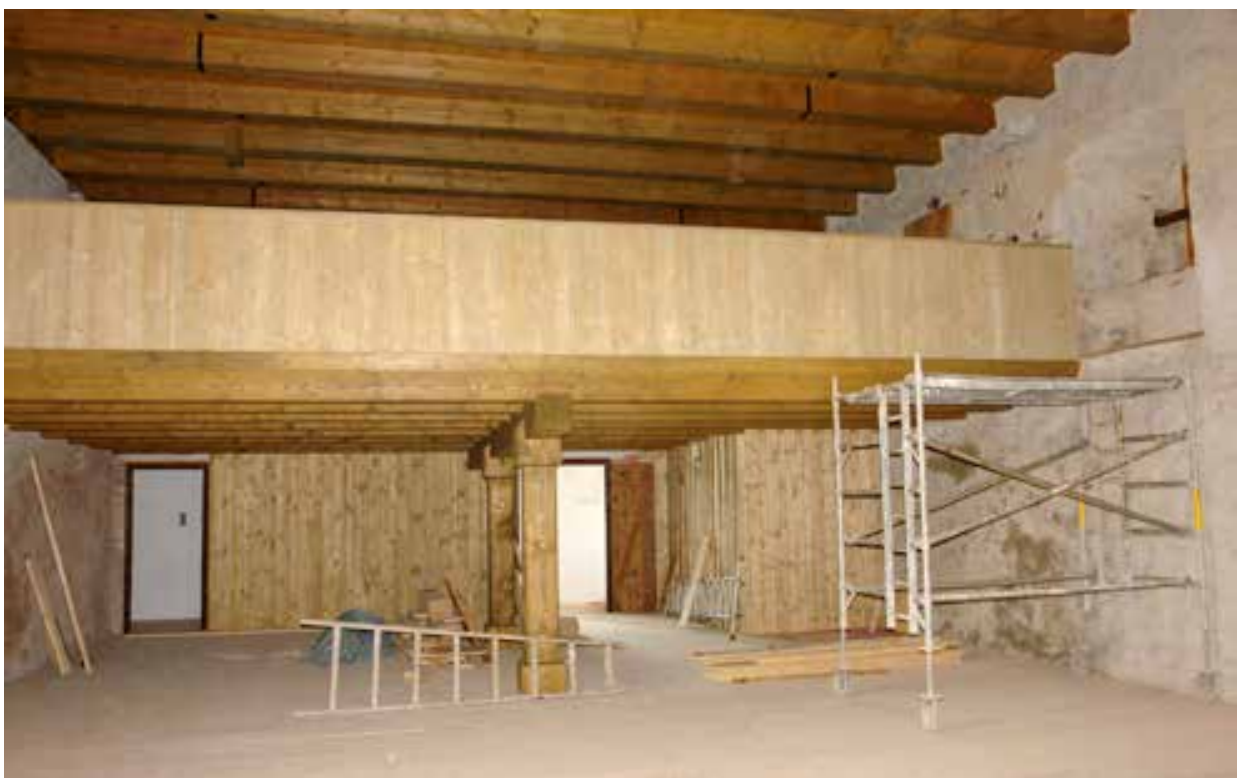

Obr. 9. Hrad Švihov, interiér sýpky. Foto J. Varhaník, 2006.

Abb. 9. Burg Schwihau, Interieur des Speichers. Foto J. Varhaník, 2006.

uvedl: „Společenský vývoj konečně pokročil natolik, že feudál se postupně proméňoval v uvědomělého majitele velkostatku se zájmem o růst zemédělské produkce a s ni spojených ziskü. Tato činnost byla spojena s budováním rozsáhlých hospodář́ských zařizení s pivovary, sladovnami, sýpkami a dalšimi hospodářskými objekty.“ (Lancinger-Muk 1975, 146) Stavba švihovského 
špýcharu není blíže datována, nicméně se jeví jako opodstatněný předpoklad, že stavební činnost na obvodu předhradí navázala na radikální přestavbu a rozšíření jádra hradu, přičemž podle tvaru bašt lze usuzovat, že byla právě na jižní straně zahájena a pokračovala směrem k severu, kde jsou v poslední dochované kurtině dendrodata dokládající, že kuláč lešení pod korunou hradby pochází z borovice smýcené v zimě 1504/1505, prričemž duby, z nichž byly zhotoveny části ochozu, byly smýceny v zimě 1501/1502 a 1502/1503 (Varhaník-Kyncl 2016, 177). Špýchar je tedy možné důvodně přičítat ještě stavební aktivitě Půty Švihovského z Rýzmberka († 1504) na sklonku 15. století. Půta náležel k nejvýznamnějším magnátům doby vladislavské a úspěšně rozšířil základnu rodové moci o řadu statků. Podle J. Janáčka $(1971,81)$ však šlo o hospodaření ještě s primitivními středověkými tendencemi vedoucími k závislosti na úvěru, zatímco vlastních ekonomických možností Půta ani jeho synové racionálně nevyužívali, což bylo jedním, byt' nikoli hlavním, z důvodů pozdějšího bankrotu tohoto rodu. Toto velice příkré hodnocení úrovně šlechtického podnikání Švihovských, kontrastující s výše uvedenou představou J. Muka, nevyvrací ani novější literatura, byt' zmiňuje zájem o těžbu kovů a určité aktivity v oblasti rybnikářství (Lhoták-Tejček 2013, 33).

S pozdně gotickou výstavbou hradu Švihova souvisela soudobá stavební činnost na hradě v Bechyni za Šternberků, kteří jej drželi od roku 1477 (Durdík 2005, 12-15). Zatímco podobnosti žebrových kleneb si povšimla D. Menclová (1972, 2, 329), další úzké souvislosti obou velkých hradů byly rozpoznány na základě stavebněhistorického průzkumu SÚRPMO (Lancinger-Muk 1968; Muk 1975; 1979). J. Muk zejména zdůraznil význam pozdně gotické sýpky při východním okraji rozsáhlého předhradí bechyňského hradu. Její budova obdélného půdorysu obsahovala dvoulodní sklep zaklenutý křižovými klenbami bez žeber, zcela shodnými s takovýmito klenbami v obou palácích na Švihově, a další tř́i plochostropá podlaží. Stavba vrcholí strmou valbovou střechou. Další podobnost shledal v utváření sedlových portálů a dokonce dospěl k závěru, že se na stavbě obou hradů účastnila jediná stavební hut' a výstavbu bechyňské sýpky zařadil před rok 1518, kdy bylo panství rozděleno (Muk 1979, 115-116).

Výskyt těchto velikých sýpek na třech významných šlechtických hradech $\mathrm{v}$ pozdní gotice, přičemž žádný z nich neleží v úrodném kraji, vzbuzuje určité rozpaky. Stavba

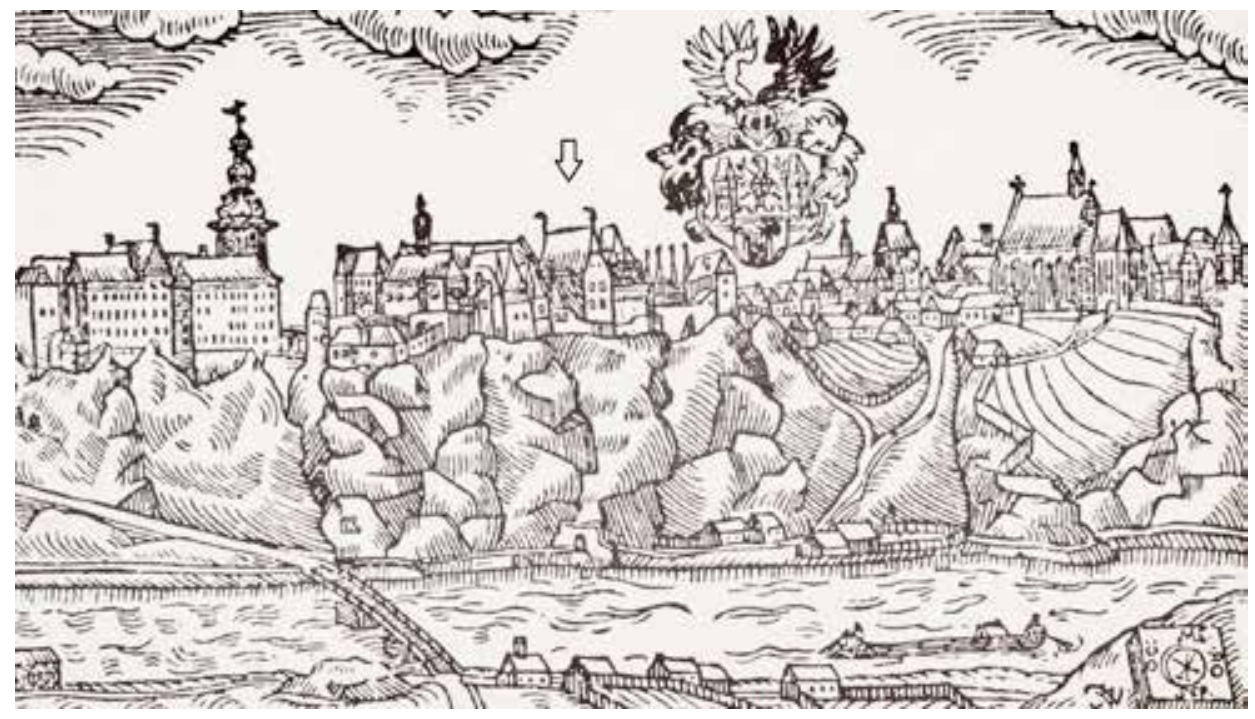

Obr. 10. Bechyně, pohled na zámek od jihu. Dřevoryt J. Willenbergera z počátku 17. století, budova sýpky je označena šipkou. Zdroj archiv J. Varhaníka.

Abb. 10. Bechin, Blick auf das Schloss von Süden. Holzschnitt von J. Willenberg vom Anfang des 17. Jahrhunderts, mit Pfeil gekennzeichnet das Gebäude des Speichers. Quelle Archiv J. Varhaník. 


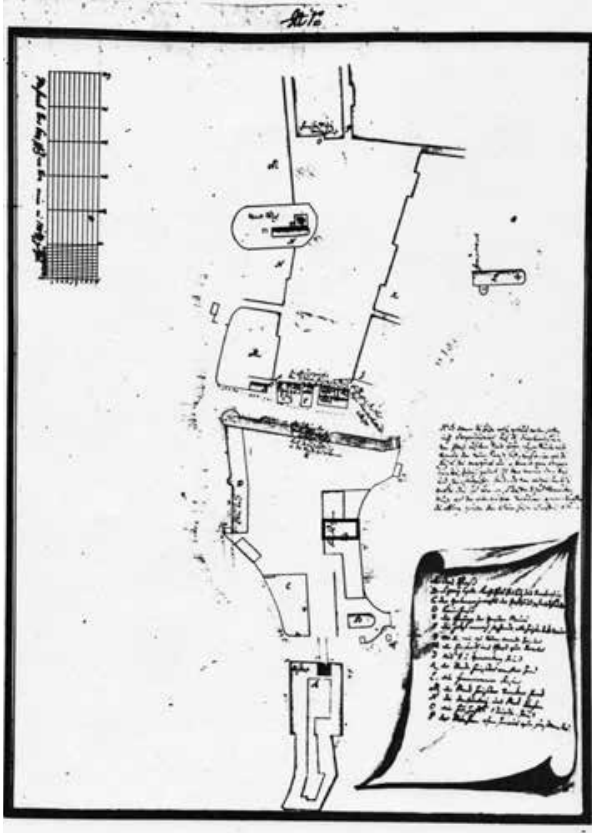

Obr. 11. Bechyně, plán zámku s předzámčím $z$ doby před rokem 1776. Obrys sýpky vyznačen silnější čarou. Podle Muk 1968.

Abb. 11. Bechin, Planskizze des Schlosses mit Vorschloss aus der Zeit vor 1776. Umriss des Speichers fett gekennzeichnet. Nach Muk 1968.

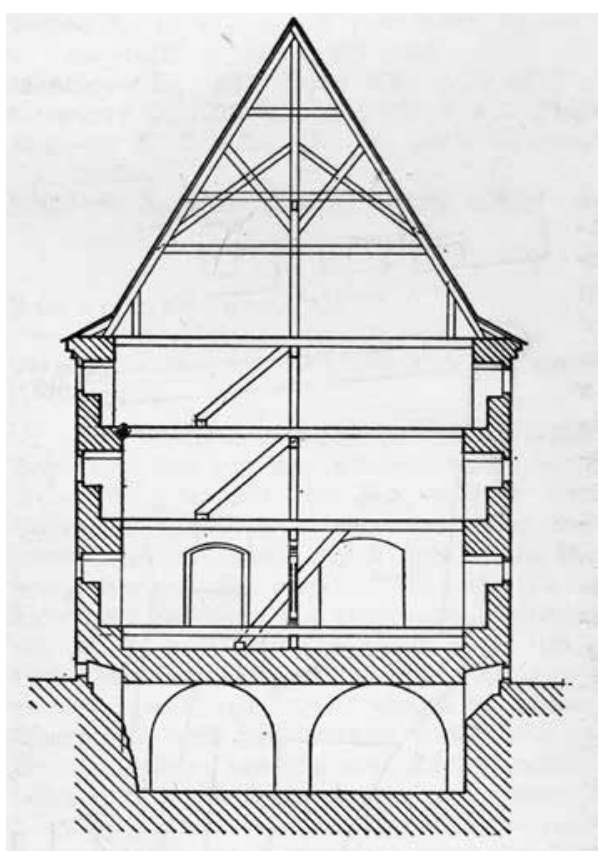

Obr. 12. Bechyně, příčný řez budovou sýpky. Podle Muk 1979.

Abb. 12. Bechin, Querschnitt des Speichergebäudes. Nach Muk 1979.

dendrochronologicky spolehlivě datované sýpky na moravském hradě Pernštejně byla v druhé fázi dokončována někdy po roce 1470 za vleklého válečného konfliktu a názory dosavadní literatury nenasvědčují tomu, že by již v této době mohlo být v rámci pernštejnského podnikání efektivní ve vlastní režii shromažd’ovat na poměrně odlehlém hradě obrovské množství obilí. Podobné stavby sýpek nejsou známy ani z pozdních let vlády Viléma z Pernštejna na dalších pernštejnských hradech - jak na Helfštejně (Plaček 2011, 213-217), Liticích (Durdík 1999, 339341) či Potštejně (Durdík 1999, 443-445), tak ani na Kunětické Hoře (Durdík 1999, 309-311) a v Pardubicích (Durdík 1999, 419-421) ležících v úrodném Polabí. V důsledku zániku předhradí je obtížné posoudit situaci na Hluboké, kterou Vilém z Pernštejna získal do zástavy v roce 1490, avšak ikonografické prameny nenasvědčují existenci žádné nápadně velké stavby, kterou by bylo možné s prŕípadnou sýpkou spojovat (Varhaník 2004). Pouze v Hranicích je za Pernštejnů předpokládán vznik nevelké sýpky, která však nebyla situována $\mathrm{v}$ jádře hradu, ani $\mathrm{v}$ jeho nově připojeném předhradí, ale kupodivu zaujala místo krajní domovní parcely při městské hradbě (Plaček 1995, 222-225).

Sýpka na Švihově - oproti Pernštejnu přibližně o jednu generaci mladší - se jeví dokonce v přímém protikladu k výše uvedenému negativnímu hodnocení šlechtického podnikání Švihovských z Rýzmberka. Pozoruhodná je situace na jejich druhém velkém hradě, Rabí. V literatuře zde sýpka uváděna není, právě tak jako v textové části elaborátu stavebněhistorického průzkumu (Lancinger-Líbal 1970), avšak v analytických plánech je tak označeno křídlo tzv. Starých pokojů. Jak bylo zjištěno archeologickým výzkumem, hospodářské využití související s pivovarnictvím se zde soustřed’ovalo zejména do jeho nejbližšího okolí, přičemž existence sýpky je 
předpokládána $v$ patrech nad prostorem sladovny (Foster 2011, 226). Přrípadné skladování obilí $\mathrm{v}$ těchto místech tedy zajisté souviselo s provozem pivovaru a rozměry těchto prostor nejsou se švihovskou sýpkou srovnatelné. Majetek Švihovských byl kromě někdy značně vzdálených zástavních statků soustředěn do dvou oblastí kolem jejich největších hradů - Švihova, v jehož bližším i širším okolí jim patřilo přes 50 vsí, a Rabí, kde vlastnili na 60 vsí (Holý 1960, 58). Racionální důvody pro př́ípadnou koncentraci veškerého obilí z těchto panství na Švihově, at' již by byl jeho původ jakýkoli, lze jen sotva odhadnout.

Alternativní interpretace k účelu uvedených staveb se však nenabízí - výše uvedené stavebněhistorické průzkumy nezjistily v jejich rozměrných interiérech žádná otopná zařízení, ani stopy vnitřního dělení. Eventualitu, zda zejména v př́ípadě v Bechyně a Švihova nepředstavovaly samostatné výstavné budovy sýpek, zjevně předimenzovaných pro potřeby dominikálního hospodářství, spíše poněkud neobvyklý způsob šlechtické reprezentace nežli součást plně funkčního hospodářského zázemí hradu, bude třeba ještě prověřit.

\section{Literatura}

BOUKAL, J., 2017: Hospodářská instrukce jako pramen poznání života na hradech na prahu raného novověku (Na příkladu instrukce pro křivoklátského hejtmana Albrechta z Vřesovic z roku 1528) - Wirtschaftinstruktionen als Mittel zur Erforschung des Burglebens an der Schwelle zur frühen Neuzeit (Am Beispiel der Instruktion des Hauptmanns von Křivoklát, Albrechts z Vřesovic, aus dem Jahr 1528), CB 17, 155-171.

CIM II: Codex juris municipalis regni Bohemiae II. Privilegia královských měst venkovských v království Českém z let 1225-1419 (Čelakovský, J., ed.). Praha 1895.

ČECHURA, J.-KUTHAN, J., 1982: Grangie v Plasích? Umění XXX, 273-276.

DURDÍK, T., 1983: Hospodářské objekty a doklady výroby na hradech v povodí Berounky a v severním Podbrdsku - Wirtschaftsobjekte und Produktionsbelege auf Burgen im Flussgebiet der Berounka und im nördlichen Podbrdsko, AH 8, 471-478.

- 1995: Encyklopedie českých hradů. Praha.

- 1999a: Ilustrovaná encyklopedie českých hradů. Praha.

- 1999b: Nejbližší zázemí hradu Křivoklátu - Das nächste Hinterland der Burg Křivoklát, AH 24, $263-272$.

- 2005: Ilustrovaná encyklopedie českých hradů. Dodatky 2. Praha.

DURDÍK, T.-BOLINA, P., 2001: Středověké hrady v Čechách a na Moravě - Mittelalterliche Burgen in Böhmen und Mähren. Praha.

FOSTER, L., 2011: Archeologický doklad sladovny na hradě Rabí - Archaeological evidence of a malt-house at Rabí castle, Sborník prací z historie a dějin umění 6, 215-231.

FRB II: Fontes rerum bohemicarum II. (Emler, J., ed.). Pragae 1874.

FROLEC, V., 1982: K interpretaci geneze trojdílného komorového domu ve světle archeologických výzkumů na jihozápadní Moravě - Zur Interpretation der Genesis des Wohnspeicherhauses im Lichte der achäologischen Forschungen in Südwestmähren, AH 7, 67-77.

GABRIEL, F.-KNOP, K., 1990: K interpretaci džbánovitých objektů na pískovci - Zur Interpretation krugartiger Objekte im Sandstein, AH 15, 261-274.

GABRIEL, F.-KRACÍKOVÁ, L., 2016: Královský palác a kaple na hradě Bezdězu a jejich proměny - Die Entwicklung des Königlichen Palas und der Kapelle der Burg Bezděz, CB 16, 46-43.

GABRIEL, F.-PANÁČEK, J.-PODROUŽEK, K., 2011: Helfenburk, hrad pražských arcibiskupů - Helfenburk - Burg der prager Erzbischöfe. Dř́ísy.

HLOŽEK, J., 2006: Předhradí vrcholně středověkých hradů - Die Vorburgen der hochmittelalterlichen Burgen, CB 10, 31-38.

HLOŽEK, J.-KŘIVÁNEK, R.-MENŠÍK, P., 2011: Kozí hrádek (okr. Tábor). Předhradí nebo hospodářské zázemí? - Die Burg Kozí hrádek im Bezirk Tábor - eine Vorburg, oder Wirtschaftliches Hinterland? AH 36, 223-242.

HOFMANN, G., 1984: Metrologická příručka. Plzeň - Sušice.

HOLÝ, V., 1960: Růst a rozklad rodového majetku Švihovských z Rýzmberka a pánů z Rožmitálu, Minulostí Plzně a Plzeňska III, 45-79.

GRAUS, F., 1957: Dějiny venkovského lidu v Čechách v době předhusitské II. Praha. 
CHOTĚBOR, P.-SMETÁNKA, Z., 1985: Panské dvory na české středověké vesnici - Herrenhöffe im mittelalterlichen Dorf Böhmens (13.-16. Jahrhundert), AH 10, 47-56.

JANÁČEK, J., 1971: České dějiny I-I. Doba předbělohorská 1526-1547. Praha.

KAŠIČKA, F., 1985: Hospodářské zázemí drobných feudálních sídel ve středních Čechách - Das wirtschaftliche Hinterland der kleinen Feudalsitze in Mittelböhmen, AH 10, 57-65.

KLÁPŠTĚ, J., 2012: Proměna českých zemí ve středověku. Praha.

KRAJÍC, R.-ŠMAHEL, F., 1988: Opevněná sídla vyšší a nižší šlechty. In: Šmahel, F., Dějiny Tábora I.1, 116-121. České Budějovice.

LANCINGER, L.-LÍBAL, D., 1970: Hrad Rabí, stavebně historický průzkum, SÚRPMO, ulož. na ústředním pracovišti NPÚ v Praze.

LANCINGER, L.-MUK, J., 1968: Bechyně, stavebně historický průzkum zámku a předzámčí, SURPMO, ulož. na ústředním pracovišti NPÚ v Praze.

- 1975: Hrad Švihov, stavebně historický průzkum, SÚRPMO, ulož. na ústředním pracovišti NPÚ v Praze.

LHOTÁK, J.-TEJČEK, M., 2013: Nejvýznamnější objednavatelé pozdně gotického umění v jihozápadních Čechách. In: Obrazy krásy a spásy. Gotické umění v jihozápadních Čechách - Images of Beauty and Salvation. Gothic Art in South West Bohemia (Jindra, P.-Ottová, M., edd.), 31-47. Řevnice - Plzen̆.

LÍBAL, D., 2001: Katalog gotické architektury v České republice do husitských válek. Praha.

LÍBAL, D.-PAVLÍK, M., 1980: Románská budova klášterního hospodářského dvora v Plasích, Umění XXVIII, 515-518.

MACEK, J., 1992: Jagellonský věk v českých zemích (1). Praha.

- 1994: Jagellonský věk v českých zemích (2). Praha.

- 1999: Jagellonský věk v českých zemích (4). Praha.

MENCLOVÁ, D., 1953: Švihov, státní hrad a městečko. Praha.

- 1956: Kozí hrádek. Praha.

- 1972: České hrady. 1, 2. Praha.

MENCLOVÁ, D.-WAGNER, J., 1965: Kost. Praha.

MĚŘÍNSKÝ, Z., 2007: Hrad Rokštejn. Brtnice - Brno.

MUK, J., 1975: Bechyně - zámecký špýchar. Nálezová zpráva doplňujícího stavebně historického průzkumu průčelí, SÚRPMO, ulož. na ústředním pracovišti NPÚ v Praze.

MUK, J., ml., 1979: Chrám sv. Jiří a gotický špýchar v Bechyni - Die St. Georgs-Kirche und der gotische Speicher der Burg Bechyně, AH 4, 113-117.

MUSIL, F., 2006: Úvod do kastelologie. 1. část. Hradec Králové.

NOVÁK, D., 2016: České „tvrze“: kritická analýza současného stavu poznání - Böhmische „Festen“: eine kritische Analyse des gegenwärtigen Erkenntnisstand, CB 16, 123-152.

PANÁČEK, M., 2003: Otopné zařízení obytného sálu ve Velké věži na hradě Kost, Svorník 1, 129-140.

PETRÁŇOVI, J. a L., 2000: Rolník v evropské tradiční kultuře. Praha.

PLAČEK, M., 1995: Fortifikační systém Hranic na Moravě - Fortifikationssystem der Stadt Hranice na Moravě, AH 20, 219-232.

- 2001: Ilustrovaná encyklopedie moravských hradů, hrádků a tvrzí. Praha.

PLAČEK, M.-DEJMAL, M. a kol., 2015: Veselí nad Moravou. Středověký hrad v říční nivě - Veselí nad Moravou - Medieval Castle in alluvial plain. Brno.

RYNEŠOVÁ, B.-PELIKÁN, J., edd., 1954: Listář a listinář Oldřicha z Rožmberka. IV. Praha.

SAMEK, B.-PLAČEK, M.-STEHLÍK, M.-HOLÍKOVÁ, P., 1997: Pernštejn, stř̌edověký hrad na Moravě. Brno.

SEDLÁČEK, A., 1932: Hrady, zámky a tvrze království českého III. Praha.

- 1935: Hrady, zámky a tvrze království českého VIII. Praha.

SMETÁNKA, Z., 1989: K problematice trojdílného domu v Čechách - Zur Problematik des dreiteiligen Hauses in Böhmen, AH 14, 319-324.

ŠABATOVÁ, L., 2016: Dokumentace budovy sýpky na hradě Pernštejně. In: Dějiny staveb 2016, 129-142. Plzeň.

ŠKABRADA, J., 1978: Sýpka domů v Pfaffenschlagu ve světle struktury vesnického domu jihočeské oblasti (,Š́je“ vesnických sýpek a středověkých zemnic) - Speicher der Häuser in Pfaffenschlag im Lichte der Dorfhausstruktur des Südböhmisches Gebietes („Hals“ der Dorfspeicher und mittelalterlicher Halbgrubenhäuser), AH 3, 355-369.

ŠVEHLA, J., 1920: Kozí. Tábor.

UNGER, J., 1991: Dokončení archeologického výzkumu vnitřního hradu v Lelekovicích, okr. Brno-venkov - Abschussgrabung in der inneren Burg von Lelekovice (Bez. Brno-Land), AH 16, 233-239. 
VARHANÍK, J., 2004: Goticko-renesanční opevnění hradu Hluboké nad Vltavou - Befestigung der Burg Hluboká nad Vltavou aus der Zeit der Gotik und der Renaissance, AH 29, 357-362.

VARHANÍK, J.-KYNCL, T, 2016: Pozůstatky hradebního ochozu na hradě Švihově - Die Wehrgangreste in der Burg Švihov, Svorník 14, 171-184.

VOHRYZEK, S.-KOVÁŘ, J. J.-HLAVICA, J., 2015: K velikosti panství hradů na jihozápadní Moravě před husitskými válkami - On the Extent of Castle Domains in Southwest Moravia Before the Hussite Wars, Studia archaeologica brunensia 20, č. 1, 133-152.

VONDRA, J., 1958: Kozí hrádek. In: Hilmera, J., Hrady a zámky, 148-149. Praha.

VOREL, P., 1999: Páni z Pernštejna. Praha.

\section{Zusammenfassung}

\section{Zur Existenz von Speichern auf mittelalterlichen Burgen}

Die Meinungen der bisherigen Literatur zur Existenz von Speichern auf mittelalterlichen Burgen in den Ländern Böhmens sind nicht einheitlich. Falls sich auf einer Burg ein Speicher befand, handelte es sich in einigen Fällen dabei um einen in der Vorburg gelegenen Bestandteil eines herrschaftlichen Hofes. Die Erkenntnisse über die ursprüngliche mittelalterliche Bebauung von Vorburgen sind jedoch allgemein unzulänglich; bei der in großen Teilen der Burg Veselí nad Moravou (Wessely) durchgeführten archäologischen Grabung wurde keines der dort entdeckten achtzehn baulichen Objekte als Speicher interpretiert. Die früher als Zisternen oder Kerker angesehenen, im Sandstein eingetieften Objekte konnten kaum als Vorratsspeicher für Getreide dienen, wie dies vor einiger Zeit vorgeschlagen wurde, da sich Kohlenmonoxid in dem porösen Sandstein nicht gehalten und sich kein Selbstkonservierungseffekt eingestellt hätte. Der in einem Steingebäude in der Kernburg von Kozí Hrádek (Ziegenburg) gemachte Fund von Getreide ist kein Beleg für die Existenz eines Saatgutvorrats, es handelte sich dabei offenbar um einen für den täglichen Bedarf bestimmten Vorrat. Die ungewöhnlich geformten kleinen Fenster des großen Turms von Burg Kost sind ebenfalls kein Beleg dafür, dass dessen Innenräume als Speicher genutzt worden wären.

Auf den Burgen hat man freilich die für den direkten Gebrauch bestimmten notwendigen Vorräte gehalten. Die zu deren Lagerung genutzten Räume hatten sich jedoch zu keinem irgendwie charakteristischen Bautyp entwickelt. Der gegenwärtige Erkenntnisstand über die bauliche Form von Burgen deutet darauf hin, dass ein Speicher, der dazu diente, Saatgut für die künftige Saison zu lagern, kein regelmäßiger Bestandteil von ihnen war, da die Burgen im Zusammenhang mit der Lagerung von Saatgut im Rahmen der ländlichen Wirtschaft keinerlei Funktion erfüllten.

Einen auffälligen Kontrast dazu bilden ausgedehnte Bauten aus der Zeit der Spätgotik, die sich auf den bedeutenden Adelsburgen Pernštejn (Pernstein), Švihov (Schwihau) und Bechyně (Bechin) befinden und in der neueren Literatur als Speicher interpretiert werden, die jedoch auf anderen großen Burgen jener Zeit nicht vorkommen. Der Grad der Unternehmertätigkeit des Adels erreichte damals noch keinen solchen Umfang wie in der zweiten Hälfte des 16. Jahrhunderts und entpricht keiner solchen Nutzung. Es stellt sich deshalb die Frage, ob diese wenigen Fälle von für die Bedürfnisse einer dominikalen Wirtschaft überdimensionierten Speichern nicht eher Ausdruck einer ausgefallenen Repräsentation des Adels waren, als Bestandteil eines völlig funktionsfähigen wirtschaftlichen Hinterlandes der hier aufgeführten Burgen.

JUDr. Jiří Varhaník, Orlík nad Vltavou 26, 39807 Orlík nad Vltavou, Česká republika, jiri.varhanik@gmail.com 
